\title{
Checklist of Pacific Operculina (Convolvulaceae), Including a New Species ${ }^{1}$
}

\author{
G. W. Staples ${ }^{2}$
}

\begin{abstract}
A new species of Operculina (Convolvulaceae), O. polynesica Staples, is described from the Pacific. This brings to five the number of species known from Micronesia, Melanesia, and Polynesia. A key for identification is provided, nomenclature and distributions are summarized, and a list of specimens examined is included to aid herbarium curators in naming Pacific material.
\end{abstract}

Botanical Literature for the Pacific records two species of Operculina from the islands and archipelagoes that make up Micronesia, Polynesia, and Melanesia. Naming of unidentified specimens in several herbaria and examination of diverse Pacific collections labeled $O$. turpethum (L.) Silva Manso revealed that at least two species were masquerading under this name. One Malesian species just reaches into the southwestern Pacific islands of Melanesia. Unexpectedly, a new species was discovered among unidentified Polynesian material. This brings to five the number of Operculina species distributed in the Pacific archipelagoes.

\section{MATERIALS AND METHODS}

A key is presented to identify the Pacific Operculina species, the new species is described and named, and a brief synopsis of taxonomic and distributional information is provided for all five species. Format for this paper conforms to that adopted for the synopsis of Australasian Lepistemon (Staples in press) and the series of papers to follow it. Relevant literature is cited to enable access to full descriptions, synonymies, detailed distributional data, and ethnobotanical information. Herbarium acronyms follow the online version of Index Herbariorum (http://sciweb.nybg .org/science2/IndexHerbariorum.asp). An identification list of Pacific specimens examined (Appendix) concludes the paper.

RESULTS

KEY TO Operculina IN THE PACIFIC

1. Stems terete, striate (grooved due to shrinkage during drying), or slightly ridged ..... 2

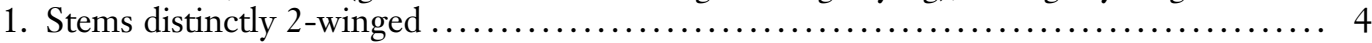

2. Vegetative parts \pm pubescent (glabrate in age); corolla flaring funnelform, 5-6.5(-8.0)

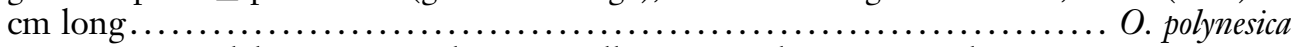

2. Vegetative parts glabrous or nearly so; corolla campanulate, $4-5 \mathrm{~cm}$ long .......... 3

3. Inflorescence bracts oblong, 1-1.5 cm long, deciduous; corolla yellowish, interplicae densely sericeous outside; ovary and style glabrous; accrescent sepals broadly rounded or emarginate. O. riedeliana

1 This material is based upon work supported by the National Science Foundation under grant no. 0212762.

Pacific Science (2007), vol. 61, no. 4:587-593

(C) 2007 by University of Hawai'i Press

All rights reserved
Additional support was provided by the Loy McCandless Marks Botanical Endowment at Bishop Museum. This is contribution no. 2006-007 from the Pacific Biological Survey. Manuscript accepted 14 March 2006.

${ }^{2}$ Formerly Bishop Museum, Botany, 1525 Bernice Street, Honolulu, Hawai'i 96817-2704

(e-mail: gstaples@bishopmuseum.org). 
3. Inflorescence bracts broadly ovate to orbicular, $2-6 \mathrm{~cm}$ long, persistent; corolla white, glabrous outside; ovary and style base shining white villous; accrescent sepals obtuse, mucronulate................................................ . ventricosa

4. Outer sepals pubescent, ovate to broadly ovate, acute to shortly acuminate and mucronulate at apex, tan to brownish in fruit; leaf blade lanceolate, ovate, to

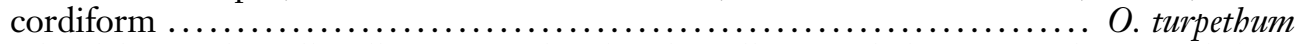

4. Sepals glabrous, broadly elliptic to orbicular, broadly rounded at apex, deep reddish brown in fruit; leaf blade \pm broadly triangular, base truncate to subcordate, margins undulate toward attenuate apex

O. brownii

The key is based on dried specimens, so sizes and colors are derived from pressed herbarium material. The distinctive reddish brown color of the calyx of O. brownii is unmistakable in herbarium material.

1. Operculina brownii Ooststr., Blumea 3:366, 1939; Fl. Males. I, 4:456, 1953; Fl. Nouv.Calédonie 13:32, 1984. Type: based on the same type as I. alata $\mathrm{R}$. Br.

Ipomoea alata R. Br., Prodr. 484, 1810.Convolvulus alatus (R. Br.) Spreng., Syst. 1:596, 1824. Type: Australia, islands near Cape Wilberforce, 22 Feb. 1803, R. Brown s.n. [sub 7.7. Bennett 2742] (holo, вм, n.v., photo!; iso, к, n.v), non Operculina alata (Ham.) Urban (1902).

Ipomoea bufalina misapplied; Operculina turpethum misapplied.

distribution: Malesia (Van Ooststroom 1939, 1953), Australia (Northern Territory).

Distribution in the pacific: Polynesia: French Polynesia-Marquesas (Eiao, Hivaoa, Nuku Hiva, Tahuata); Tonga: Vavau. Melanesia: Fiji (Ngau, Vanua Levu); New Caledonia.

NOTES: Smith (1991) included Fijian specimens of $O$. brownii in his concept of $O$. turpethum. Specimens from the Marquesas have been misidentified as O. turpetbum (Sachet 1975). Operculina brownii is known from Tonga based on a single specimen [Vavau, June 1891, C.S. Crosby 126 (к)]; it is possible that this is wrongly labeled because the species has never been collected in Tonga again.

The type material for I. alata $\mathrm{R}$. Br. (and hence of O. brownii) was not found in вм; its whereabouts is unknown. However a photo- graph taken of the specimen circa 1979 for Robert Johnson, which the latter kindly shared with me, establishes the taxonomic concept adopted here. Heine (1984) pointed out that the corollas of New Caledonian specimens are densely silky-hairy; in all other respects they are typical of the species. I have confirmed that this is the case; other Pacific material seen has glabrous corollas, as described by Van Ooststroom (1939).

\section{Operculina polynesica Staples, n. sp.} Figure 1

Type material: Pitcairn Islands, Henderson Island, South West Point, 15 May 1991, 7. Florence, Chepstov-Lusty \& Waldren 10,909 (holo к!; iso BISH!, вм, СHR, E, L!, Р!, PTBG, TCD!, us!).

Description: Ab alteris Operculinae Pacifici Oceani speciebus inflorescentiae caducis 1.1-1.3 cm longis bracteis, glabris sepalis cum rotundo vel praemorso apice, tenue infundibuliformi 5.0-6.5 cm longa corolla, praecipue differt.

A robust twiner or prostrate trailer; stems herbaceous, terete or striate, 5-14 mm diam., finely puberulous to glabrate, fistulose. Leaf petiole (2.0-)5.5-9.5(-13.5) cm long, sulcate; blade broadly cordiform, suborbicular to broadly ovate, $9.3-21 \times 8.6-20 \mathrm{~cm}$, herbaceous to slightly fleshy, base broadly cordate, apex tapering acuminate to cuspidate, mucronulate, adaxial side appressed sericeous to glabrous, abaxial side villous to subglabrous, trichomes denser along veins. Inflorescences axillary, cymose, 1- to 3-flowered; peduncles stout, 5.0-12.4(-18.0) cm long; branches (6-)17-20 mm long; bracts paired, elliptic to oblong, 1.1-1.3 cm long, incurved around pedicel, caducous; pedicels angulate, 2.0-4.3 


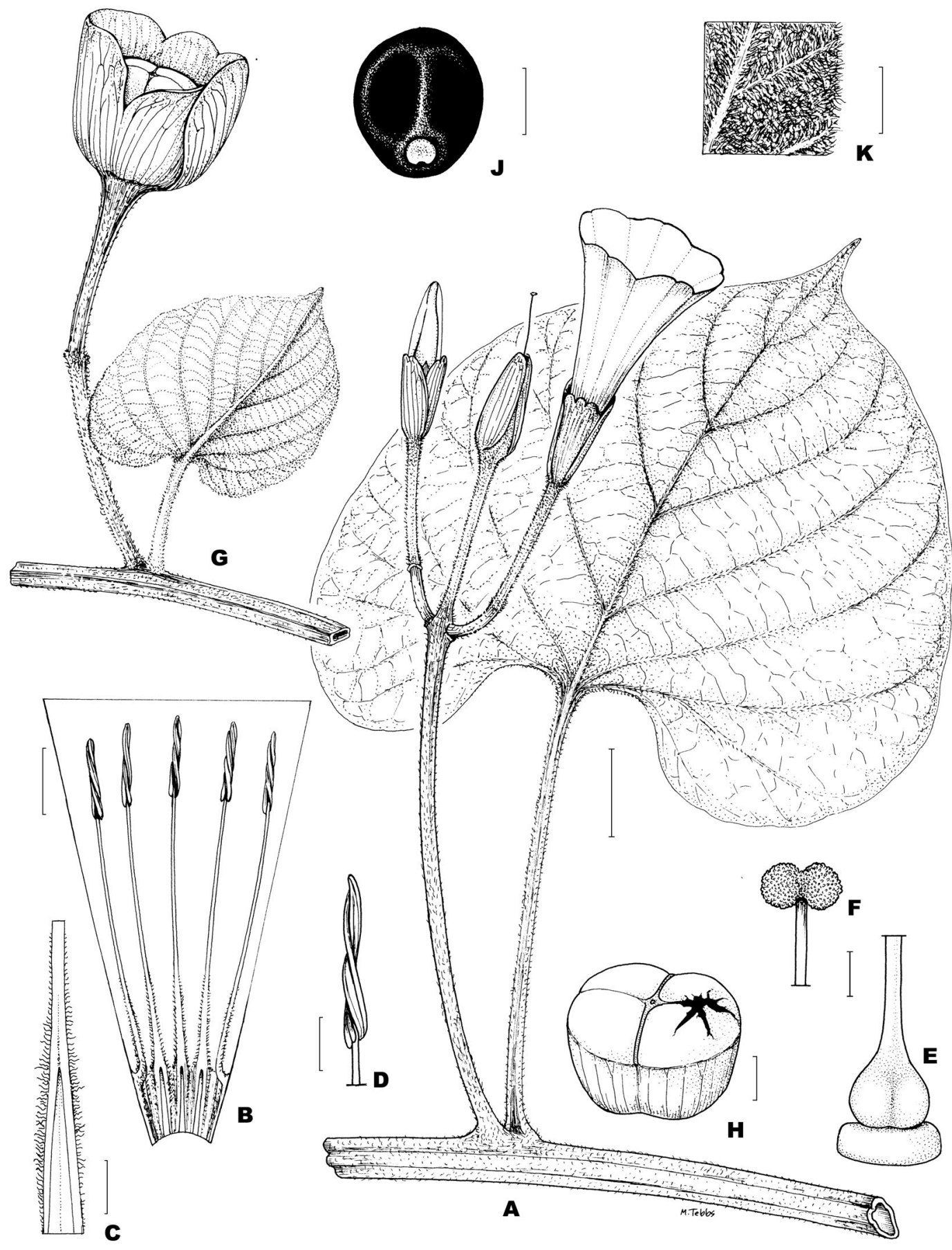

Figure 1. Operculina polynesica, n. sp. $A$, Flowering branch, scale $=20 \mathrm{~mm} ; B$, corolla opened to show stamens, scale $=5 \mathrm{~mm} ; C$, filament base, scale $=2 \mathrm{~mm} ; D$, anther, scale $=2 \mathrm{~mm} ; E$, ovary and disk, scale $=1 \mathrm{~mm} ; F$, stigma, scale $=1 \mathrm{~mm} ; G$, fruiting branch; $H$, utricle, scale $=5 \mathrm{~mm} ; \mathcal{F}$, seed, scale $=5 \mathrm{~mm} ; K$, indumentum on leaf underside, scale $=5 \mathrm{~mm}(A-F$ and $K$ from Florence 7,$034 ; G-7$ from Florence et al. 10,909). 
$\mathrm{cm}$ long, thickened and clavate in fruit (then thicker than peduncle). Flowers showy, diurnal, odorless. Calyx clasping base of corolla tube, sepals broadly elliptic to subcircular, \pm equal or inner slightly shorter, $18-23 \mathrm{~mm}$ long; outer 3 rounded, emarginate to praemorse apically, margins entire, glabrous or finely puberulous medially; inner 2 obtuse, mucronulate, glabrous; all 5 enlarging in fruit, adaxially stramineous and shiny, finely pitted, abaxially tan to pale brownish, (sub)glabrous, enclosing the fruit. Corolla flaring funnelform, $5-6.5 \mathrm{~cm} \times 3.5-4.5 \mathrm{~cm}$, white, outside glabrous; stamens subequal, 18-20 $\mathrm{mm}$ long, filaments pubescent on basal $1 / 3$, glabrous above; anthers spirally dehiscent, 4-6 mm long, white. Pistil 30-33 mm long, disk annular, wider than ovary, blackish; ovary ovoid, ca. $3 \mathrm{~mm}$ long, glabrous; style filiform, stigmas 2, globose. Fruit an operculate capsule, ca. $3.0 \times 2.5 \mathrm{~cm}$, glabrous, circumscissile above the middle; operculum not seen; endocarp thinly papery, translucent. Seeds 4 or less, carinate, black, 10 $12 \mathrm{~mm} \times$ ca. $10 \mathrm{~mm}$, glabrous, surface finely roughened, matte; hilum basal, reniform to semicircular, ca. $4 \times 5 \mathrm{~mm}$, yellowish in center.

Distribution: Widely distributed across Polynesia from Tonga, Niue, and the Cook Islands (Atiu) via the Tuamotus to the Pitcairn Islands (Henderson).

ECOLOGY: Found at elevations from sea level to $35 \mathrm{~m}$, apparently always on coral substrates.

PHenology: Flowering: June, July, October; fruiting: May, October.

Label data from Cook Islands specimens (Sykes 3740/CI and 3878/CI) indicate that the fresh corollas are as much as $7.0-8 \mathrm{~cm}$ long and 8-9.0 cm across the limb. The largest corollas seen in dried material are $6.5 \mathrm{~cm}$ long.

SPecimens examined: Tonga: Ha'apai group, Kao, 6 Aug. 1982, Buelow 3,093 (віsн); Tofua, 'Akava, ca. $1.5 \mathrm{~km} \mathrm{~W}$ of Hokula, 13 June 1982, Buelow 2,585 (вімн); Vavau, no date, Crosby 129 (к). Niue: Tautu, near Liku, 27 Oct. 1965, Sykes 169,783 (віsн). Cook Islands: Atiu, Teenui Distr., coast road near Taunganui Harbour, 23 July 1991, Sykes 3,740/CI (BISH), ibid., airport, 30
July 1991, 3,878/CI (віSн). French Polynesia: Tuamotu Archipelago, Tikehau, motu du village de Tuherahera, 26 Oct. 1984, Florence 7,034 (вISн, к, Р). Pitcairn: Henderson Island, SW Point, $300 \mathrm{~m}$ E of camp, 15 May 1991, Florence, Chepstov-Lusty \& Waldren 10,909 (вISH, к, L, Р, тCD, Us); ibid., 22 June 1991, 10,989 (вISH, к, L, P, TCD, US).

Two sterile collections that appear, based on foliage and indumentum characters, to be conspecific follow: French Polynesia: Tuamotu Archipelago, Niau, Tupana, secteur SE, 1 Apr. 1990, 7. Florence 10,180 (віsн, к, Р, us); Rangiroa, Motu Otepipi, 19 Jan. 1992, Florence 10,008 (BISH, K, P, Us).

NOTES: It is hoped that further collecting in the Tuamotus will provide fertile specimens that can be identified with certainty. These two specimens have been included in the Appendix with a ? to indicate uncertainty. For a discussion of intermediate populations between $O$. polynesica and $O$. ventricosa, see under the latter species.

3. Operculina riedeliana (Oliv.) Ooststr., Blumea 3:366, 1939; Fl. Males. I, 4:57, 1953.

Ipomoea riedeliana Oliv., in Hook., Icones III, 5: t. 1424, 1883.-Merremia riedeliana (Oliv.) Hallier f., Engl. Bot. Jahrb. 16:552, 1893. Type: [Indonesia] Buru, sine loco, Riedel s.n. (holo к!).

Additional synonyms and misapplied names are given by Van Ooststroom (1939).

Distribution: Andaman Islands, extreme southern Thailand, throughout Malesia and New Guinea (Van Ooststroom 1939, 1953).

Distribution in the pacific: Melanesia: Solomon Islands (Kolombangara).

Notes: This species is widespread, but nowhere common, throughout Malesia and just reaches Southeast Asia to the northwest and the Solomon Islands in the east. The Kolombangara specimen is the first report of the species from so far east in the Pacific.

4. Operculina turpethum (L.) Silva Manso, Enum. Subst. Braz. 16, 1836.

Convolvulus turpethum L., Sp. Pl. 155, 1753.-Ipomoea turpethum (L.) R. Br., Prodr. 485, 1810.-Merremia turpethum (L.) Rendle, 
in Thiselton-Dyer, Fl. Trop. Africa 4 (2): 102, 1905. Type: Ceylon, sine loco, Hermann herbar. 2: 68 (lecto вм!).

The species has an extensive synonymy; additional synonyms pertinent to the Pacific may be found in Van Ooststroom (1939), Staples and Austin (1981), and Fang and Staples (1995). Furthermore, Pacific authors have confused genuine $O$. turpethum with at least two other species (O. brownii, O. polynesica).

distribution: Widespread in the Old World tropics including India, Bangladesh (Khan 1985), Myanmar (Kress et al. 2003), Thailand (Staples et al. 2005), China (Fang and Staples 1995), Vietnam (Nguyen 1990), and throughout Malesia (Van Ooststroom 1939, 1953). Also introduced and naturalized in the West Indies (Staples and Austin 1981).

distribution in the pacific: Micronesia: Federated States of Micronesia (Ifaluk Atoll, Ponape, Truk); Belau (Palau Islands: Angaur). Polynesia: Cook Islands (Mitiaro, Rarotonga); French Polynesia: Society Islands (Bora-Bora, Tahaa, Tahiti); Hawaiian Islands (Hawai'i); Samoa (Tau, Upolu). Melanesia: Fiji (Matuku, Mothe, Ovalau, Somasomo, Vanua Levu, Viti Levu); New Caledonia; New Guinea (Papua and Indonesian); Rotuma; Solomon Islands (Guadalcanal, Rennell); Vanuatu (Anatom (= Aneityum), Vanua Lava).

Notes: Operculina turpethum has varied medicinal and ethnobotanical uses throughout Asia (Austin 1982), and its current distribution in the Pacific has surely been aided by human dispersal (for example, by the Indian population living in Fiji, who may well have brought the plant there from India). There are plants scattered throughout the Pacific that agree closely with typical $O$. turpethum from Asia. And there are numerous other island populations that have been called O. turpetbum that differ from the typical Asian forms of this species. Some of this variability is herein referred to other species. In the western Pacific (Caroline Islands, Solomon Islands, Vanuatu, New Caledonia in part), however, there are robust plants that have been included in O. turpethum (e.g., by Fosberg and Sachet 1977, Heine 1984) that may represent a distinct taxon, but further study is required to decide this. Alternatively, they may belong with the intermediates described under $O$. ventricosa, though presenting a slightly different facies.

5. Operculina ventricosa (Bert.) Peter in Engl. and Prantl, Nat. Pflanzenfam. 4, 3a:32, 1891.

Convolvulus ventricosus Bert. in Colla, Hort. Ripul. 37, 1824.-Ipomoea ventricosa (Bert.) Choisy in DC., Prodr. 9:360, 1845.Operculina turpethum var. ventricosa (Bert.) Staples and Austin, Brittonia 33:595, 1981. Type: Antilles, Bertero s.n. (то, n.v.).

Previously (Staples and Austin 1981), I interpreted the West Indian populations of $O$. ventricosa as a variety of $O$. turpethum. Study of additional Pacific material has convinced me that this was erroneous; the two taxa warrant specific rank.

Distribution: Presumed native to the West Indies (Staples and Austin 1981), from where it was first described; naturalized in the Pacific. Cultivated in India (Kerala).

distribution in the pacific: Micronesia: Guam; Northern Mariana Islands (Agrigan, Alamagan, Farallon de Medinilla, Maug, Pagan, Rota, Saipan, Sariguan, Tinian). Melanesia: New Caledonia; Vanuatu (Santo, Vaté).

Notes: Operculina ventricosa is immediately recognizable by virtue of its robust size and the enlarged, persistent inflorescence bracts, the largest known in the genus. Additional distinguishing characters noted here are the densely hairy ovary and style base, the hairs persistent in fruit, and the lower half of the exocarp is distinctly hairy even in weathered old fruits. The upper part of the exocarp (the operculum or dehiscent lid) is typically missing on herbarium specimens, and I have not been able to determine whether it is pubescent or not. Heine $(1984: 25,27)$ described and illustrated the ovary and fruits of the plants from New Caledonia as $O$. ventricosa to be glabrous; oddly, he illustrated the fruit of O. turpethum (Heine 1984:31) as distinctly hispid. In comparing duplicates of the collection McKee 37083, I noticed that the sheets in $\mathrm{K}$ and $\mathrm{L}$ were annotated by Heine in 1979 as O. turpethum; however this number is cited as $O$. ventricosa in 
the flora account (Heine 1984:28). The New Caledonian Operculina specimens require further investigation to clarify this confusion, which is no doubt where the discrepancy already noted originated.

It seems likely that human dispersal is responsible for the odd distribution of this species in the Pacific. The places where it is found correspond to points of contact where European traders with connections to the West Indies would have called: the French between New Caledonia and the French Antilles; the Spanish between Guam and the Spanish possessions in the Greater Antilles.

A number of collections of robust plants from Samoa and the Caroline Islands have not been satisfactorily placed in this study; they are morphologically intermediate between $O$. polynesica and O. ventricosa, being less hairy than the former but lacking the enlarged bracts of the latter. It is possible that hybridization brought about by humans moving plants around the Pacific could be responsible for these intermediate populations; field study is necessary to determine if this is the case. Intermediate specimens have been entered in the Appendix with " " linking the numbers representing the two species believed to be involved, for example 2 5.

\section{ACKNOWLEDGMENTS}

Study of herbarium specimens in A, B, BISH, C, $\mathrm{E}, \mathrm{G}, \mathrm{GH}, \mathrm{K}, \mathrm{L}, \mathrm{P}, \mathrm{PTBG}, \mathrm{s}, \mathrm{TCD}$, us, either in person or via loans, was enabled by the curators and staff, for which help I am most appreciative. The Latin diagnosis was translated by J. Florence (р). Margaret Tebbs (к) illustrated the new species. Bill Sykes (CHR) provided photos of the flowers for two of his specimens of $O$. polynesica. Bob Johnson (BRI) kindly shared his photograph of the type material of O. brownii.

\section{Literature Cited}

Austin, D. F. 1982. Operculina turpethum (Convolvulaceae) as a medicinal plant in Asia. Econ. Bot. 36:265-269.

Fang, R.-Z. and G. W. Staples. 1995. Con- volvulaceae. Pages 271-325 in C.-Y. Wu and P. Raven, eds. Flora of China 16. Science Press and Missouri Botanical Garden Press: Beijing and St. Louis.

Fosberg, F. R., and M.-H. Sachet. 1977. Flora of Micronesia, 3: Convolvulaceae. Smithson. Contrib. Bot. 36:1-34.

Heine, H. 1984. Convolvulaceae. Pages 1-91 in Flore de la Nouvelle-Calédonie et dépendances. 13 .

Khan, M. S. 1985. Convolvulaceae. Pages 159 in Flora of Bangladesh 30.

Kress, W. J., R. A. DeFilipps, E. Farr, and Y. Y. Kyi. 2003. A checklist of the trees, shrubs, herbs, and climbers of Myanmar. Contrib. U.S. Natl. Herb. 45:1-590.

Nguyen, T. N. 1990. Convolvulaceae. Pages 173-186 in L. V. Averyanov, N. T. Ban, N. T. Hiep, N. T. Quyen, P. K. Loc, N. N. Tzvelev (with the participation of D. D. Huyen, M. L. Samutina, and O. I. Vinogradov), eds. Vascular plants synopsis of Vietnamese flora. Vol. 1. Nauka, Leningrad.

Sachet, M.-H. 1975. Flora of the Marquesas, 1: Ericaceae-Convolvulaceae. Smithson. Contrib. Bot. 23:1-34.

Smith, A. C. 1991. Convolvulaceae. Pages 41-90 in Flora Vitiensis Nova 5. National Tropical Botanical Garden, Lāwa'i, Kaua'i.

Staples, G. W. In press. A synopsis of Lepistemon (Convolvulaceae) in Australasia. Kew Bull.

Staples, G. W., and D. F. Austin. 1981. Changes in the West Indian Operculina (Convolvulaceae). Brittonia 33:591-596.

Staples, G. W., B. Na Songkhla, C. Khunwasi, and P. Traiperm. 2005. Annotated checklist of Thai Convolvulaceae. Thai Forest Bull., Bot. 33:171-184.

Van Ooststroom, S. J. 1939. The Convolvulaceae of Malaysia, II. The genera facquemontia, Aniseia, Convolvulus, Calystegia, Shutereia, Merremia, Operculina and Decalobanthus. Blumea 3:267-371.

. 1953. Convolvulaceae. Pages 388512 in C. G. G. J. van Steenis, ed. Flora Malesiana ser. I, 4. Noordhoof-Kolff, Djakarta. 


\section{Appendix}

Index of Numbered Specimens Examined

Ahern's collector FB-1999 (4).

Bacon, P. H.-1,145/81 (3).-Balansa, B. 3,350 (1); 3,352 (5).-Batianoff, G. N. 11,432 (4).-Bennet, J. J. 2,742 (T)

(1).-Bonham, L. D. 2 (5).—Brass, L. J. 8,317 (4); 18,934 (4); 21,813 (4).—Bristol, M. L. 2,331 (2 5).—Bryan,

E. H., Jr. 241 (4); 483 (4).-Buelow, G. 2,585 (2); 3,093 (2).

Christophersen, E. 575 (4); 2,845 (2 5?).—Christophersen, E. \& E. P. Hume 2,427 (2 5).—Clarkson, J. R. 3,808

(4).-Courage, E. G. 30 (5); 54 (5).—Crosby, C. S. 126 (1); 129 (5).—Cunningham, A. 366 (4).

Degener, O. 15,404 (4).-Dupetit-Thouars 114B (1).

Evans, M. 1,474 (5); 2,191 (5); 2,337 (5).

Falanruw, M. C. MVCF-3,257 (5).-FFlorence, J. 4,024 (4); 5,354 (4); 7,034 (2); 7,543 (1); 10,008 (2?); 10,180 (2?).-

Florence, J. et al. 9,343 (1); 10,909 (T) (2); 10,989 (2). —Floyd, A. 5,766 (4).—Fosberg, F. R. 2,845 (2 5); 24,812

(5); 25,215 (5); 25,878 (2 5); 25,982 (2 5); 31,273 (5); 31,383 (5); 31,617 (5); 31,722 (5); 31,876 (5); 31,977 (2 5);

32,004 (2 5); 32,005 (2 5); 32,277 (2 5); 35,384 (5); 47,242 (4); 47,471 (2 5); 63,428 (4).

Garber, D. W. 1,099 (2 5).--Gillison, A. N. NGF-22,244 (3).-Grant, M. L. 5,121 (4).

Harris, W. 135 [lot 2459-Stat. 123] (2 5).-Hellwig, F. 101 (4).-Herbst, D. R. 7,345 (5); 7,377 (5); 7,434 (5).Herbst et al. 7,525 (5).-Hoogland, R. D. 4,311 (3).-Hosaka, E. Y. 2,857 (5).

Kairo, A. \& H. Streimann NGF-30,797 (4).—Kajewski, S. F. 450 (4).—Kondo, Y. 9 (5?).

Lange, W. H. 35 (5).-Lépine, J. 40 (4).—Luce, J.-P. 114 (1).

MacGillivray 56 (4).-Marshall, M. 92 (sterile).-McKee, H. S. 1,652 (4); 2,858 (4); 4,594 (1); 9,998 (4); 27,216 (4); 31,724 (4); 37,083 (4); 39,103 (1); 40,555 (1).-Merthems 77 (4).-Moore, G. C. 56 (5).—Moran, R. 4,523 (5).— Morris 34a (4).

Neil, P. E. SI-442 [= P. E. Neil L19] (3); SI-444 (3).

Parham, J. W. DA-10,829 (4)._Parham, Mrs. H. B. R. 346 (4); 365 (1); 536a/b (4). -Perlman, S. \& J. Florence 10,048 (1).-Powell, Rev T. 351 (4).

Raulerson, L. 16,382 (5).--Reinecke 62 (4); 545 (4).-Ribourt 39 (4).-Riley, J. C. 60 (4).

Sachet, M.-H. 1,766 (5); 1,867 (1); 2,111 (2?); 2,528 (4).-Saunders, W. W. 56 (4).- Schlechter, R. 14,729 (4).Seemann, B. 327 (4).-Smith, A. C. 7,952 (1).-Soegang Reksodihardjo 194 (4).-Stemmermann, L. 3,391 (2).St. John, H. 19,721 (4).—Stone, B. C. 4,911 (5).—Sykes, W. R. 169,783 (2); 3,562/CI (4); 3,740/CI (2); 3,878/ CI (2).

Takamatsu, M. 445 (2 5); 991b (2 5).--Tsutsui, R. 6 (5).

Uchiyama, H. et al. 241 (4 1).-CUniversity Papua New Guinea UPNG-3,614 (4).

Vandenberg, J. \& E. Mann NGF-42,210 (4).-Van Royen, P. 4,504 (4); 4,598 (4).-Versteegh \& Vink BW-8,338 (4).

Waterhouse, B. M. BMW6,578 (2 5).-Whistler, W. A. 4,410 (4); 4,487 (2 5); 5,909 (4); 6,914 (5); 10,304 (5); W-253 (2 5); W-264 (4); W-665 (2 5); W-2,842 (2 5).-Whitmee, Rev. S. J. 74 (4).-Wisner, A. W. 113 (2 5).-Wong, C.C.Y. 253 (4).

Yuncker, T. G. 9,289A (4).

Note: The specimen identifications are keyed to the species numbers used in the text. (T) signifies a type specimen; ? signifies a tentative identification (often sterile material); signifies an intermediate between two species. 
